\title{
Pilkada dan Minat Politik Konstituen terhadap Tuan Guru di Lombok Barat Tahun 2018
}

\author{
Agus Dedi Putrawan \\ UIN Mataram \\ Email: agusdediputrawan@gmail.com
}

\begin{abstract}
Abstrak: Pemilu adalah arena kompetisi untuk mengisi jabatan-jabatan politik di pemerintahan yang didasarkan pada pilihan formal dari warga negara yang memenuhi syarat, Begitupun Tokoh Agama di NTB. Tren politik Tokoh Agama di kancah daerah meningkat sejak dimulainya TGH. Zainul Majdi memenangkan dua kali Pilkada Tahun2009-2014 dan Tahun 2014-2019. Keberhasilan TGH. Zainul Majdi tidak diikuti keberhasilan tokoh-tokoh agama yang lain baik di level legislatif maupun Kabupaten Kota. Kekalahan para Tuan Guru itu pun terjadi hingga hari ini. Penelitian ini akan menguraikan hasil Pemilihan Umum Kepala Daerah di Lombok Barat Tahun 2018 yang melibatkan dua orang tuan guru sebagai calon wakil pubati melawan incumben dengan wakilnya seorang perempuan mantan ketua DPRD.

Kata Kunci: Pilkada, Tuan Guru, Tren Politik

Abstract: Election is a competition arena aimed at filling the political positions in the government resulted from the formal voting of the people who have the rights, not to mention thereligious figures in NTB. The political trend of the religious figures has gained popularity on the local level since the two consecutive winnings by TGH. M. Zainul Majdi respectively in 2009-2014 and 2014-2019 elections. His success, however, has not been replicated by other Islamic figures (Tuan Guru) both in the legislative and regent levels. The defeat of the aforementioned Tuan Guru has even happened until recently. This paper presents the election results of the local election in the regency of West Lombok in 2018, which saw two Tuan Gurus competing against the incumbent and his female candidate, the ex-legislative leader in the region.
\end{abstract}

Keywords: Local election, Tuan Guru, Political Trend 


\section{Pendahuluan}

Dalam kajian tentang kekuasaan Weber mengklasifikasikan dominasi kuasa yang terlegitimasi menjadi tiga yaitu otoritas kharisma, otoritas tradisional dan otoritas legal-formal. Sebagian orang percaya bahwa kepribadian personal dapat menggambarkan seseorang itu memiliki kekuasaan murni atau tidak. Meski belakangan ini sangat jarang terdengar namun di zaman-zaman terdahulu mayoritas orang patuh pada pribadi yang dianggap sakti, tak tertandingi, sakral dan karismatik. Orang takut akan kualat, su'ul adab, dikutuk, dan bahkan menaruh masa depan mereka kepada aktor kekuasaan tersebut, model ini disebut kharisma. Otoritas karisma ini dapat dilihat dari tokoh-tokoh legendaris seperti dukun, pemimpin perang, wali, pastor, tuan guru pada zaman dahulu.

Model kuasa yang selanjutnya berdasarkan atas adat istiadat yang dikeramatkan melalui pengakuan yang tak terbayangkan tuanya dan orientasi kebiasaan untuk menyesuaikan atas warisan nenek moyang. Inilah yang disebut dominasi "tradisional" yang mempraktikkan patriarch dan penguasa patrimornial pada zaman dahulu. Kuasa tradisional ini biasa disematkan pada tokoh-tokoh semisal kepala adat, kepala suku, raja-raja monarki, keturunan bangsawan dan lain sebagainya.

Model terkahir ini biasa dikenal dengan model kekuasaan Legal-Formal. Dominasi karena "legalitas", yakni karena keyakinan pada keabsahan statuta legal dan "kompetensi" fungsional yang didasarkan pada pranata yang diciptakan secara rasional. Dalam hal ini, kepatuhan diperlukan guna melaksanakan berbagai kewajiban berdasarkan hukum UU yang disepakati, model ini sekarang kita kenal dengan sebuatan Nation State. Proses pemberikan kekuasaan pada model ini bukan pada penyematan atau pemberian turun temurun akan tetapi dilakukan dengan jalan pemilihan umum di negara-negara demokrasi misalnya.

Bentuk pemerintahan di mana semua warga negaranya memiliki hak setara dalam pengambilan keputusan yang dapat mengubah hidup mereka. Demokrasi mengizinkan warga negara berpartisipasi, baik secara langsung atau melalui perwakilan dalam perumusan, pengembangan, dan pembuatan hukum. Demokrasi 
mencakup kondisi sosial, ekonomi, dan budaya yang memungkinkan adanya praktik kebebasan politik secara bebas dan setara, memilih dan dipilih. Peguasa pada legal foemal ini biasa dikenal dengan istilah presiden, gubernur, bupati, wali kota, kepala desa, ketua organisasi dan lain sebagainya.

Pemilihan umum hari ini sebenarnya menjadi wadah kompetisi bagi tiga modal kuasa yang saling mengadu strategi merebut simpati pemilih untuk menduduki kursi secara formal. Kontestasi dalam pemilihan umum sejatinya adalah merebut hak untuk mengelola sumberdaya yang ada di dalam wilayah yang ia pimpin. Terdapat golongan yang mengandalkan karisma, keturunan kebangsawanan, kekayaan dan kapital yang lain untuk sama-sama berkompetisi dalam pemilu. Tren pemilihan Tahun 2018 di Lombok Barat, patut menjadi perhatian. Karena dua orang tuan guru sebagai calon wakil bupati dengan modal kepatuhan jamaah dan santri yang ada di pondok pesantrennya tumbang melawan seorang perempuan mantan DPRD Kabupaten Lombok Barat. Ini menjelaskan bahwa modal otoritas karisma ketuan guruan secara informal saja tidak cukup untuk memenangkan suara terbanyak dalam pemilu demokrasi.

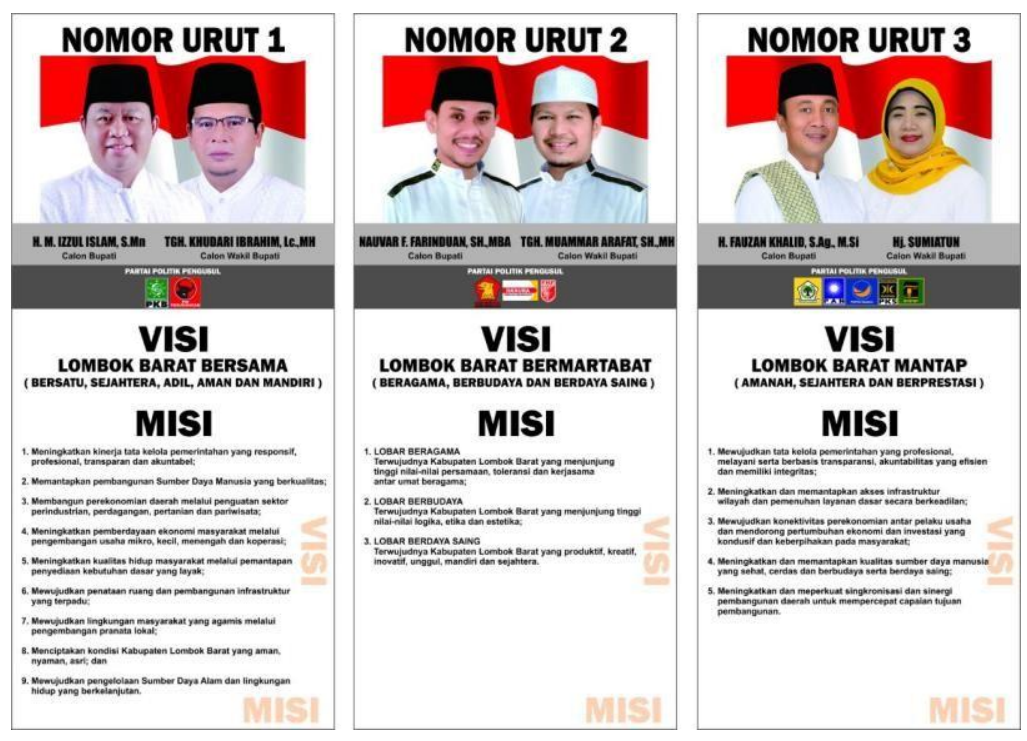

(Gambar: Tiga Paslon Pilkada Lombok Barat) 


\section{Refleksi Politik Tuan Guru}

Politik sejatinya menjadi bagian yang tak terpisahkan dari umat Islam Indonesia. Di mana tokoh-tokohnya berjuang merebut dan mengkonsolidasikan kemerdekaan. Belum lagi gerakan-gerakan politik organisasi terbesar seperti Nahdlatul Ulama yang isinya adalah kiai-kiai dan para santri mendeklarasikan resolusi jihad berjuang mengusir Inggris di Surabaya. Bagi mereka ajaran Islam mencakup segala hal termasuk ikut berpolitik praktis, sebab di dalamnya terdapat istilah dakwah dengan tindakan.

Sehingga mulai saat itulah politik menjadi istilah yang tidak aneh lagi bagi mereka. Namun di zaman orde baru para tokoh agama ditekan gerak-geriknya oleh rezim yang berkuasa termasuk berpolitik. Pengajian-pengajian yang diadakan dijaga ketat, isi pengajian diamati betul, hingga tumbang para era reformasi menemukan puncak kembalinya tokoh agama ke ranah politik praktis. Di Nusa Tenggara Barat sendiri Kemenangan TGH. Zainul Majdi dikarenakan momentum yang tepat. Karena semua calon yang ada adalah calon lama yang terlibat korupsi sehingga Tuan Guru Bajang (TGH. Zainul Majdi) adalah satu-satunya calon alternatif yang bersih. ${ }^{1}$

Meskipun sebelum reformasi terdapat Tuan Guru yang terjun dalam politik Nasional, namun akses tersebut hanya terbatas pada tokoh tunggal TGH. Zainudin Abdul Majid (alm)2 wafat 1997 mantan Kontituante masa Soekarno dan MPR masa Soeharto. ${ }^{3}$ Setelah reformasi bergulir dengan kebijakan desentralisasi di setiap daerah

${ }^{1}$ Dikutip dari tulisannya yang berjudul; Politik Islam Sasak "Tuan Guru dan Politik Pasca Orde Baru" dalam buku, Samsul Anwar, at al, Lombok Mirah Sasak Adi, hlm. 230.

2 Kiprah Tuan Guru Zainudin Abdul Majid dala $\mathrm{m}$ pe ndidikan dan politik banyak diteliti oleh pe ne liti local sebut saja salah satunya, Masnun yang berjudul “Tuan Guru KH Muhammad Abdul Majid, Gagasan dan Gerakan Pembaharuan Islam di Nusa Te nggara Barat, (Jakarta:Pustaka al-Miqdad, 2007).

${ }^{3}$ Baru setelah beliau, ada beberapa tuan guru sebagai tokoh nasional seperti Tuan Guru Turmudzi Badruddin sebagai Mustasyar PBNU. lihat. http://www.nu.or.id/a, public-m,dinamic-s,de tail-ids,1-id,22611-lang,id-c,warta t,Susunan+Pe nye suaian+PBNU+2010+2015+Re smi+Diumumkan-.phpx Kamis, 26, Maret 2015. 07:27 
hingga pada pemilu tahun 2014, seakan terlihat para Tuan Guru berbondong-bondong masuk ke dunia politik.

Namun jika diperhatikan dengan seksama, tidak ada perbedaan apa yang dialami tokoh-tokoh agama dengan para politisi biasa dalam berpolitik. Ketika sebagian Tuan Guru yang mencalonkan diri dalam pemilihan anggota Legislatif maupun kepala Kabupaten dan Daerah, banyak di antra mereka yang kalah dan berguguran meskipun ada satu, dua Tuan Guru yang terpilih. Di NTB misalnya, dalam pemilihan Dewan Perwakilan Daerah (DPRD) Provinsi tahun 2014, terdapat sembilan orang Tuan Guru yang mencalonkan diri, mereka harus tertatih-tatih untuk mendapatkan suara dan simpati rakyat, hasilnya adalah hanya empat yang lolos ke Udayana. ${ }^{4}$

Di tingkat Desa, dalam pemilihan Dewan Perwakilan Daerah (DPD) Kabupaten Lombok Barat, tepatnya di Desa Eyat Mayang, Kecamatan Lembar Kabupaten Lombok Barat, dari 41 peserta terdapat 4 orang Tuan Guru yakni; TGH. L. Nurul Wathoni S.Pd.I, TGH. L. Mara Sira'i S.Ag, Drs. TGH. Muchlis Ibrahim, M.Si, TGH. Muharrar Mahfuz. ${ }^{5}$

Di bagian timur Lombok juga banyak Tuan Guru mencalonkan diri sebagai calon legistalif, misalkan dalam pemilihan umum 2004 lalu, baik tingkat Kabupaten, Propinsi maupun Nasional, di antaranya; Pemilihan calon DPRD Kabupaten Lombok Timur; TGH. Nasruddin (dari Partai PBR), TGH. Musta'rif (dari Partai PBR). TGH. Junaidi Rasyidi Ahmad, LC. (dari Partai PBB), TGH. Mahsup (dari Partai PBB); Pemilihan calon DPRD Propinsi Nusa Tenggara Barat; TGH. Baharudin Nur Badrul Islam (dari Partai PKB), TGH. Drs. Abdul Hayyi Nu'man (dari partai PBR). TGH. Drs. M. Safi'i Ahmad, M.A. (dari Partai PBB), Calon DPR RI, TGH. Muhammad Zainul Majdi, M.A (dari partai PBB), TGH. Muhammad Anwar MZ (dari Partai PPP) TGH. Adjrul (dari Partai PPP), TGH. Salehudin LC. (dari

\footnotetext{
${ }^{4}$ Data dari Komisi Pemilihan Umum (KPU) Provinsi Nusa Te nggara Barat. Tahun 2014.

${ }^{5}$ Sertifikasi hasil pe nghitungan perole han suara dari setiap TPS di tingkat desa/kelurahan dalam pemilihan umum anggota DPD tahun 2014. Data, KPU tingkat Kecamatan, NTB, 2014.
} 
Partai PBR). Calon DPD yakni; TGH. Munajib, TGH. Muhlis Ibrahim. (keduanya berasal dari Lombok Barat). ${ }^{6}$

Telah terjadi Pragmentasi pemilih ${ }^{7}$ terhadap para Tuan Guru tersebut. TGH. L. Nurul Wathoni S.Pd.I berulang kali mendapat suara kosong di tempat pemungutan suara (TPS): $\operatorname{TPS} 1=2$, TPS $2=6$, $\operatorname{TPS} 3=3$, TPS $4=0$, TPS $5=3$, TPS $6=3$, TPS 7 dan $8=0$. Dari keseluruhan ia memperoleh 17 suara. ${ }^{8}$ Dari sini terdapat gambaran bahwa dalam pemilihan umum status sosial keagamaan pun tidak menjamin mudah tidaknya mendapatkan kursi parlemen, ada berbagai faktor-faktor lain di luar status sosial keagamaan yang dibutuhkan oleh seseorang yang hendak terjun ke politik "praktis".

Namun perlu digaris bawahi bahwa pudarnya pesona dari para Tuan Guru juga dipengaruhi oleh wilayah karisma itu sendiri. Di wilayah territorial Tuan Guru (sekitar pondok pesantren) hegemoni karisma begitu kuat sedangkan ketika keluar dari teritorialnya, semakin jauh semakin tak terlihat lagi karisma Tuan Guru. Tuan Guru Munajib misalkan bertempat tinggal di Sesela Lombok Barat, kekuatan karisma beliau begitu kuat di daerahnya (Desa Sesela) didukung juga jangkauan santri dan pengikut.

Namun karisma tersebut akan memudar ketika ia keluar jauh ke Batu Layar, Senggigi, dan Kota Ampenan. Ketika mencalon diri sebagai anggota DPD dan Bupati Lombok Barat tampak jelas garis jangkau karisma yang melekat pada diri Tuan Guru Munajib, hal yang sama juga berlaku bagi Tuan Guru-Tuan Guru lainnya (kasus karisma), TGH. L. Nurul Wathoni S.Pd.I, TGH. L. Mara Sira'i S.Ag, Drs. TGH. Muchlis Ibrahim, M.Si, TGH. Muharrar Mahfuz, TGH. Nasruddin, TGH. Musta'rif, TGH. Junaidi Rasyidi Ahmad, LC., TGH. Mahsup, TGH. Baharudin Nur Badrul Islam, TGH. Drs. Abdul Hayyi Nu'man, TGH. Drs. M. Safi'i Ahmad, M.A, TGH. Muhammad Zainul

${ }^{6}$ Sumber Data, KPU Kabupaten Lombok Timur Tahun 2005.

${ }_{7}$ Terjadi pragmentasi ini juga disinggung oleh Miftahussurur, Pasang Surut dan Pragme ntasi Politik Islam di Indone sia, dalam Jurnal Pe ne litian dan Kajian Keagamaan (Dialog), (vol. 72. no. 2, Tahun. XXXIV, Nopember 2011), hlm. 26-41.

${ }^{8}$ Sertifikasi hasil pe nghitungan perole han suara dari setiap TPS di tingkat desa/kelurahan dalam pemilihan umum anggota DPD tahun 2014. Data, KPU tingkat Kecamatan, NTB, 2014. 
Majdi, M.A, TGH. Muhammad Anwar MZ, TGH. Adjrul, TGH. Salehudin LC, TGH. Muhlis Ibrahim.

\section{Analisi Hasil Survey}

Survey adalah aktivitas Untuk melihat keterkenalan (popularitas) dan keterpilihan elektabilitas, Untuk mengetahui basis masa calon, Untuk menjadi acuan bagi tim untuk mengambil langkah kampanye dan untuk Evaluasi diri tim pemenangan.

1. Ketentuan Pelaksanaan Survei Independen

a. Survei dilaksanakan di wilayah kabupaten Lobar dari 10 Kecamatan, 122 Desa. Dengan jumlah surveyor 122 orang.

b. Berdasarkan data dari Giri Menang Kominfo, sumber berita DPT Per-31 Maret 2017 berjumlah 493.487 Orang, sehingga penentuan responden yang akan menjadi sampel setiap desa dengan mengunakan teori $1 \%$ atau 0,01 dari Populasi DPT. Berjumlah 4.148 Responden dengan penyebaran 34 sampel setiap Desa

c. Teknis perhitungan $n$ sehinga jumlah responden

setiap desa 34 orang, jika pembagiannya ganjil maka dibulatkan menjadi rata-rata seperti: ada yang 4 dan 5 maka dibulatkan rata-rata 5.

d. Penentuan responden dengan mengunakan key responden (Tokoh Masyarakat: Kepala Dusun) kemudian sisanya ditambah masyarakat umum dengan mengunakan interval 3, mulai dari sebelah kanan rumah kepala dusun.

e. Responden dengan representasi 50\% laki-laki dan 50\% perempuan.

f. Survei dilaksanakan maksimal 5 Hari,

\section{Hasil Survey}

Survey di laksanakan tanggal 8 s/d 11 Maret Tahun 2018 dengan jumlah surveyor lapangan 66 dan koordinator lapangan 10 orang serta penanggung jawab 5 orang, Jumlah DPT 472, 237. Sampel yang digunakan dalam survey ini adalah 500 Responden, dengan 
melihat 10 Kecamatan, 122 Desa yang ada di seluruh Lombok Barat. Jumlah TPS perkecamatan di Kabupaten Lombok Barat, Kecamatan Kuripan 69 TPS, Batu Layar 90 TPS, Lembar 94 TPS, Kediri 101 TPS, Sekotong 114 TPS, Labuapi 118 TPS, Lingsar 122 TPS, Gunung Sari 146 TPS, Gerung 156 TPS dan Kecamatan Narmada 170 TPS.

Melihat reperesentatif dengan melibatkan Key Responden yaitu 1 Orang kepala dusun, 2 Orang Tokoh, untuk warga masyarakat 3 orang laki-laki dan 2 orang Perempuan disetiap Desa. Dengan mengunakan dua teknik yaitu Kuantitatif melalui prosedur penyebaran angket dan kualitatif dengan pengamatan dan wawancara mendalam.

\section{LOMBOK BARAT}

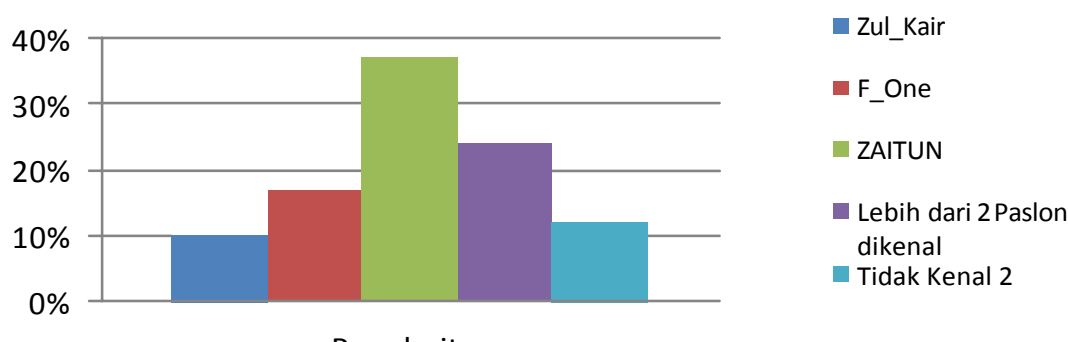

Popularitas

(Gambar: Hasil Survey Keterke nalan)

Dari hasil survey yang dilakukan menunjukkan paslon nomer urut satu dengan tuan guru sebagai wakilnya mendapatkan popularitas $10 \%$, Paslon nomer urut dua dengan tuan guru sebagai wakilnya mendapatkan popularitas $17 \%$ sedangkan nomer urut tiga mendapatkan popularitas sebesar $37 \%$, pemilih yang mengenal lebih dari dua paslon yang dikenal sebanyak $24 \%$ sedangkan $12 \%$ pemilih menyatakan tidak mengenal semua pasangan calon. Ini artinya bahwa para tokoh agama dengan keterkenalan karisma yang dimilikinya hanya sebatas teritorialnya saja, tidak bisa menjangkau seluruh kabupaten di Lombok Barat. 


\section{LOMBOK BARAT}

Zul_Kair $\quad$ F_One $\square$ ZAITUN $\square$ Tidak Memilih

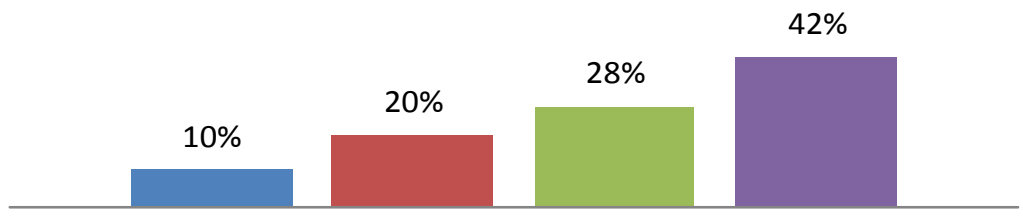

Elektabilitas

(Gambar: Hasil Survey Keterpilihan)

Dari hasil survey yang dilakukan menunjukkan paslon nomer urut satu dengan tuan guru sebagai wakilnya mendapatkan elektabilitas sebesar $10 \%$, Paslon nomer urut dua dengan tuan guru sebagai wakilnya mendapatkan elektabilitas sebesar $20 \%$ sedangkan nomer urut tiga mendapatkan elektabilitas sebesar $28 \%$, sedangkan $40 \%$ pemilih menyatakan akan memilih.

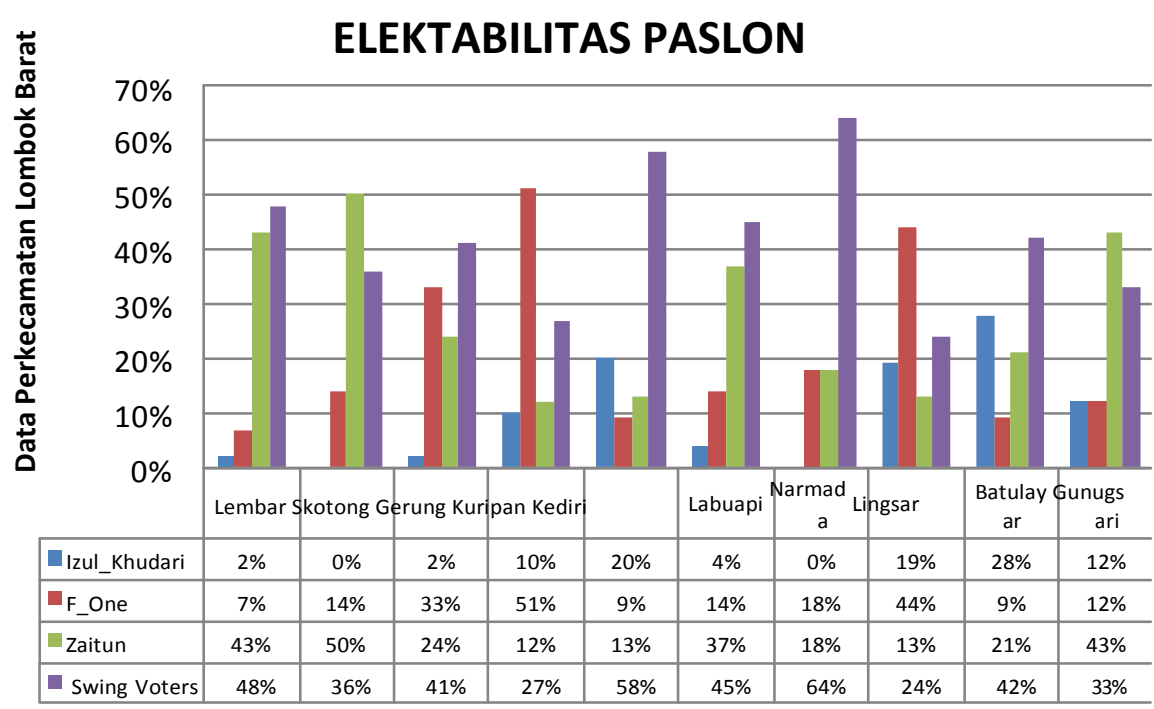

(Gambar: Hasil Survey Keterpilihan Perkecamatan) 
Data elektabilitas Pasangan Calon Bupati dan Wakil Bupati Kabupaten Lombok Barat untuk paslon No Urut 1 izul-Khudari di Kecamatan Lembar 2\%, Sekotong 0\%, Gerung 2\%, Kuripan 10\%, Kediri 20\%, Labuapi 4\%, Narmada 0\%, Lingsar 19\%, Batu Layar 28\% dan Gunung Sari 12\%. Sedangkan paslon no urut 2 F-One memperoleh elektabilitas di Kecamatan Lembar 4\%, Sekotong 14\%, Gerung 33\%, Kuripan 51\%, Kediri 9\%, Labuapi 14\%, Narmada 18\%, Lingsar 13\%, Batu Layar 21\% dan Gunung Sari 43\%. Dan Paslon No Urut 3 Zaitun dengan elektabilitas di wilayah Kecamatan Lembar $48 \%$, Sekotong $50 \%$, Gerung 24\%, Kuripan 12\%, Kediri 13\%, Labuapi $37 \%$, Narmada 18\%, Lingsar 13\%, Batu Layar 21\% dan Gunung Sari $43 \%$. Sementara Swingvoters di Kecamatan Lembar sebesar 48\%, Kecamatan Sekotong 36\%, Kecamatan Gerung 41\%, Kecamatan Kuripan 27\%, Kecamatan Kediri 58\%, Kecamatan Labuapi 45\%, Kecamatan Narmada 64\%, Kecamatan Lingsar 24\%, Kecamatan Batu Layar 42\%, dan Kecamatan Gunung Sari 33\%.

\section{Faktor Keterpilihan Tuan Guru}

Paling tidak ada beberapa hal yang membuat para Tuan Guru (pemilik umat) terjun ke politik, Komaruddin Hidayat dan M. Yudhie Haryono menyebutnya dengan rasionalisasi ulama, atau tindakan yang menyadarkan mereka untuk melakukan empat hal penting; efisiensi, prediksi, kuantitasi, dan pragmatisasi. ${ }^{9}$

\section{Perubahan Sistem Pemerintahan}

${ }_{9}^{9}$ Pola laku e fisie nsi bermakna bahwa para ulama sadar diri terhadap jabatan publik sebagai saran e fisie $\mathrm{n}$ untuk melakukan peme nuhan cita -cita dan visi ideal sebuah bangsa. Mereka ingin keluar kandang kare na sumpek melihat elit Negara atau politii busuk yang sudah lama beredar di masyarakat. Pola pikir prediksi bermakna pilihan rasional dan hitung-hitungan matematis dan spekulatif de ngan tujuan keme nangan. de ngan prediksi kawan dan lawan para ulama meresa mampu meme nangkan festival demokrasi. Sedangkan tingkah pragmatis dimaknai sebagai pilihan jangka pe nde $\mathrm{k}$ tanpa harus terlalu dipusingkan oleh untung -rugi di masa depan. Lihat. Komarudin dan Haryono, Mane uver Politik Ulama “Tafsir Kepemimpinan Islam dan Dialektika Ulama -Negara" (Yogyakarta: Jalasutra, 2004), hlm 2-3. 
Nazar Naamy berpandangan bahwa memudarnya peran Tuan Guru di masyarakat khusus dalam penelitiannya di Lombok Barat, terjadi karena perubahan struktur pemerintahan nasional, sejak orde lama, orde baru menuju orde reformasi. ${ }^{10}$ Dahulu Tuan Guru menjadi tempat bersandar segala referensi kehidupan termasuk politik, menjadi penafsir perpolitikan nasional karena keterbatasan yang dimiliki pengikutnya (ilmu pengetahuan, informasi dan jaringan).

Masyarakat Sasak pada waktu itu menjunjung tinggi Tuan Guru di samping karena kekecewaannya terhadap pemerintah yang otoriter juga terhadap karisma Tuan Guru yang dianggap masyarakat mengetahui segala hal di luar diri mereka, sehingga tidak jarang masyarakat sasak menyandarkan segala sesuatu kepada Tuan Guru. Namun setelah reformasi, hal di atas mulai mengikis, terjadi share kekuasaan yang dulunya yang bersifat sentralistik menjadi desentralisatik. ${ }^{11}$

Pada tahap ini timbul penguasa-penguasa baru di tingkat lokal, bersaing merebut kedudukan dalam pemerintahan melalui pemilihan umum (pemilu) yang sebelumnya banyak dikuasai oleh militer "Back to Barrack". Aktor-aktor politik baru ini kemudian bermunculan menjadi fungsionaris yang bergelut di berbagai bidang kehidupan masyarakat, menyangkut hajat hidup orang banyak seperti Kepala Desa, Bupati, Gubernur, dan Para Dewan Perwakilan. Mereka melayani keperluan-keperluan sosial kemasyarakatan, mengurusi kesejahtraan masyarakat luas seperti; pendidikan, kesehatan, lapangan pekerjaan, serta kebutuhan-kebutuhan ekonomi masyarakat.

${ }^{10}$ lebih lanjut te ntang refleksi pasang surut politik islam dari orde lama hingga orde re formasi, lihat Abdul Wahid, Populisme Akar Ketahanan Politik Ide ntitas: Refleksi Pasang Surut Politik Islam dari Orde Lama hingga Orde Reformasi, dalam Jurnal Pe ne litian dan Kajian Keagamaan (Dialog), (vol. 72. no. 2, Tahun. XXXIV, Nopember 2011), hlm. 97-112.

${ }^{11}$ Ketika dikonfirmasi terkait pe ne litiannya Nazar Naamy, Seorang Pe ne liti politik Tuan Guru di Lombok, Desertasinya berjudul “ Prilaku Politik Tuan Guru dalam Pemilihan Umum Kepala Daerah (Pe milukada) Studi Prilaku Politik Tuan Guru dalam Dinamika Politik Lokal di Kabupaten Lombok Barat. Diterbitkan de ngan judul "Poligami Politik Tuan Guru". beliau me njadi dosen tetap di Fakultas Dakwah, IAIN Mataram. Wawancara, 8 Februari 2015. 


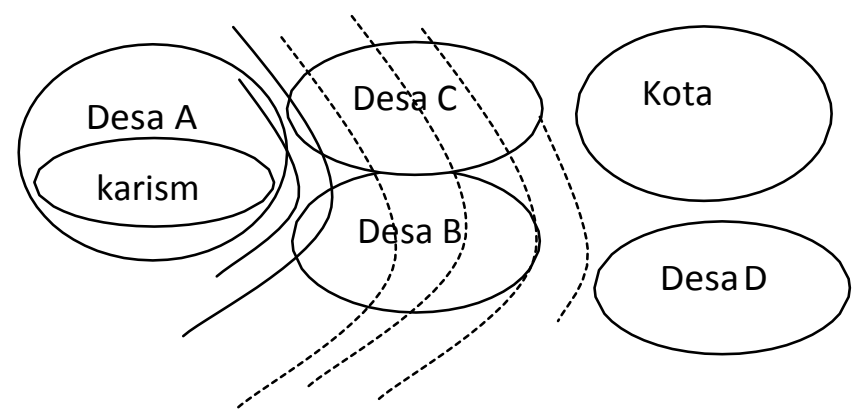

Teritorial Kekuatan Karisma Tuan Guru

\section{Perselingkuhan Tuan Guru dengan Penguasa}

Hubungan antara Tuan Guru dan penguasa di pulau Lombok akan melahirkan steriotipe dari masyarakat awam, terlebih bagi mereka yang berhubungan dengan aktor yang sudah dikabarkan dengan status jelek di masyarakat meskipun secara hukum belum dapat dibuktikan. Seharusnya, Tuan Guru sebagai tokoh panutan berdiri di atas semua kekuatan politik; tidak memuhak pada satu kekuatan politik tertentu. Peran ini menurut Subkhan akan sirna manakala Tuan Guru sudah mengkubu pada salah satu kekuatan politik. ${ }^{12}$

\section{Beda Afiliasi dengan Pengikut}

Banyak dari para santri tersebut berbeda partai dengan Tuan Gurunya, dengan alasan bahwa para santri lebih dahulu membangun karir politiknya di suatu partai politik dibandingkan Tuan Guru yang baru-baru memegang bendera partai. Kehormatan terhadap Tuan Guru tidak akan pernah hilang namun di dalam urusan politik siapa sangka mereka akan berbalik, adu strategi, adu siasat untuk meraih simpati konstituen mereka karena masalah politik pasti juga berbicara hitung-hitungan, kalkulasi jumlah suara dan lain sebagainya.

${ }^{12}$ Imam Subkhan, Karisma dan Hegemoni Politik Kiai dalam Kompas, 13 Maret 2004. 
Salah satu contoh dalam penelitian ini adalah Ahmad Riadi yang bersebrangan dengan TGH. Takiuddin. Ahmad Riadi alias Rebeq mengatakan, titik kesalahan sebenarnya berpangkal pada sistem Negara yang amburadul, di mana sistem yang membuat orang menjadi korupsi, money politik dan lain sebagainya. Sedangkan Tuan Guru yang terjun ke politik berahlak mulia, masuk ke dalam sistem yang rusak maka ada dua kemungkinan. Pertama, dia akan mewarnai dan memberikan perubahan; Kedua dia yang akan terseret dan hanyut oleh orang-orang di dalam sistem yang rusak itu.

“Dalam politik, Tuan Gurusudah tidak didengar lagi, bahkan di wilayahwilayahlainnya pula, sikap bertele-tele dari Tuan Guru membuatjamaah terpolarisasi, lari ke sana-ke mari akibat Tuan Guru lompat dari satu partai ke partai lainnya. Dahulu ketika Tuan Guru memakai bendera PPP semua warga Desa memakai bendera PPP dan bendera lain tidak boleh masuk ke desa kami. Namun setelah Tuan Guru berganti bendera maka kepercayaan terhadap Tuan Guru mulai memudar, kini banyak benderabendera partai bertebaran di mana-mana, bahkan santrinya pun berbeda bendera dengan Tuan Gurunya." 13

Namun bisa saja dalam beberapa kasus karisma Tuan Guru yang tetap bertahan karena fakta kefanatikan pengikut. Sebobrok apapun sang Tuan Guru, berpindah-pindah partai politik, meskipun tindakan Tuan Guru nyata melakukan suatu hal yang salah menurut para analis, dus tetap saja menang dan diikuti. Karisma dalam hal ini berbicara tentang kefanatikan pengikut, ${ }^{14}$ maka menurut Weber karisma akan memudar manakala para pengikut sudah rasional.

\section{Pragmatisme Para Pemilih}

Dalam pesta demokrasi hari ini siapa saja yang memberi uang yang dipilih (coblos), sebab zaman sekarang ini semua calon sama saja, ketika hari kampanye mencari rakyat, kalau sudah selesai pemilihan semua calon yang jadi menghilang. Bersalam-salaman

13 Ahmad Riadi, tokoh adat Desa Bonde $r$ Kabupaten Lombok Te ngah. Wawancara, 20 Februari 2015.

${ }^{14}$ Fe nome na ini dalam ranah politik praktis disebut oleh Zuly Qodir de nga n istilah mistifikasi politik kiai, lihat. Zuly Qodir, Islam Syariah vis -à-vis Negara "Ideology Gerakan Politik di Indone sia",(Yogyakarta: pustaka pelajar, 2007), hlm. 141-144. 
ketika belum jadi menang pemilu, tapi ketika sudah jadi mereka tidak berani bersentuhan dengan rakyat. Tuan Guru maupun bukan Tuan Guru, tidak menepati janji kampanye mereka. Masyarakat beranggapan bahwa dari pada dibohongi lebih baik ambil uangnya, sepuluh calon memberi uang, ke-sepuluhnya diambil.

Ketidak tahuan masyarakat tentang pendidikan politik inilah yang membuat para Tuan Guru yang tidak bermain curang (money politik) ditenggarai menjadi faktor kekalahan para Tuan Guru. TGH. Munajib menyadari dari sekian modal untuk berpolitik, salah satu yang paling urgent adalah faktor dana. ${ }^{15}$ Apa yang dirasakan TGH. Munajib juga dirasakan TGH. Azami dalam kontestasi 2014. Ia tercatat sebagai caleg 2014 dari PKS, ${ }^{16}$ sejak pencalonannya masyarakat mulai bimbang, bahkan ia merasa sedih ketika diberikan uang oleh salah satu jamaahnya dengan alasan bahwa calon dari Tuan Guru adalah calon miskin. ${ }^{17}$

Bermacam-macam istilah yang lahir di tengah-tengah masyarakat sasak pada musim kampanye, misalkan istilah "serangan fajar", entah dari mana datangnya istilah ini. Istilah serangan fajar artinya pemberian uang kepada individu-individu konstituen di waktu fajar sebelum para konstituen berangkat mencoblos pada jam 7 pagi.

Kedua istilah "amplop suare", istilah ini lahir ketika para konstituen menukarkan foto copy KTP mereka dengan sejumlah uang, plus stiker partai berserta calon yang akan dipilih, dengan kesepakatan bahwa konstituen bersedia memilih. Ketiga "ngerampek suare", merampek sendiri dalam konteks politik disematkan pada hal yang negatif, ngerampek artinya menuai padi, panen padi, istilah ini lahir ketika seorang calon memenangkan suara pada dapil tertentu

${ }_{15}$ Modal dalam berpolitik me nurutnya adalah usaha, do'a dan dana. TGH. Munajib, terdaftar sebagai Calon DPD (2005) Calon Wakil Bupati Lombok Barat (2014) Wawancara, 21 Januari 2015. lihat juga Sumber Data, KPU Kabupaten Lombok Barat Tahun 2005. dan Sumber Data, KPU NTB Tahun 2014.

${ }_{16}$ Sumber Data, KPU Kabupaten Lombok Timur Ta hun 2014.

${ }_{17}$ TGH. Azami, pernah me netap di mekkah selama satu tahun untuk me nimba ilmu, sekarang ia tercatat sebagai mahasiswa Pascasarjana UIN Sunan Kalijaga Yogyakarta, Wawancara di kos, di kawasan Sape n, 23 Maret, 2015. 
kemudian cara-cara kemenangannya dengan membeli suara yang sudah diketahui masyarakat, sehingga masyarakat sasak biasanya mengatakan "menang ngerampek suare".

\section{Faktor Gaya Hidup Tuan Guru}

Tuan Guru di tengah masyarakat dikenal dengan kesederhanaannya, sikap hidup apa adanya selalu mereka tampilkan tatkala berhadapan dengan jamaahnya. Biasanya memakai baju sederhana, sarung dan peci haji ketika mereka bergumul di pelosok pelosok desa yang dikelilingi oleh persawahan.

Jarang terlihat Tuan Guru memakai kaca mata hitam, memakai celana jeans, topi koboi, dan lain sebagainya yang merefleksikan fashion zaman sekarang. Sikap kesederhanaan itu membuat hubungan antara Tuan Guru dengan jamaahnya begitu harmonis, jarang terlihat sikap segan menyapa Tuan Guru oleh jamaahnya, pertemuan mereka intens terjadi baik di mushola atau masjid, maupun dalam pengajian-pengajian yang diselenggarakan di area pondok pesantren. Berbeda halnya ketika berbicara sebagian Tuan Guru kekinian, mereka di tengah-tengah masyarakat menjadi kaum elitis.

\section{a. Poligami}

Poligami adalah hal yang biasa terjadi di masyarakat Sasak, ${ }^{18}$ Budaya poligami adalah budaya yang menguntungkan kaum lakilaki "patrilinear", "superioritas" sedang yang merasa dirugikan adalah kaum perempuan "second sex", "subordinasi", laki-laki boleh menikahi perempuan lebih dari satu tapi dengan syarat "adil".

18 Term poligami di masyarakat Sasak me nurut Bianca: “The term polygamy refers to the practice of multiple marriage. The broad meaning of polygamy includes the practice of polyandry (whe $\mathrm{n}$ a woman is married to more than one man) and polygyny (whe $n$ a man is married to more than one woman). In this article I use the term polygamy rathe $r$ than polygyny because in my fie ld site locals employed the Indone sian term poligami (polygamy) to describe the practice. The y used the term madu to re fe r to co- wives." Lihat, Bianca J Smith, Stealing Wome n, Stealing Me n: Co-cre ating Cultures of Polygamy in a Pesantre n Community in Eastern Indone sia, (Re port Information from ProQuest, 30 April 2015 11:21), hlm.15. 
Berbicara poligami di tengah-tengah masyarakat Sasak akan ditemukan dua pandangan yang bertentangan, yaitu yang mendukung dan menolak. Secara umum masyarakat yang mendukung berasal dari kaum laki-laki sedangkan yang menolak poligami kalau ditarik secara umum adalah kaum perempuan.

\section{b. Gaya Hidup Elitis Konsumtif}

Bagi para Tuan Guru yang terjun ke politik, pertemuan dengan jamaah mereka sangat jarang, dikarenakan terbentur jadwal pemerintah (bagi yang sudah menjadi pejabat maupun pengurus partai). Bentuk penghormatan masyarakat Sasak kepada Tuan Guru biasanya dengan mengundangnya dalam setiap hajatan-hajatan, baik perkawinan, hitanan, selametan, pengajian dan lain-lain, namun penghormatan terhadap Tuan Guru akan memudar ketika undanganundangan oleh masyarakat tidak pernah dipenuhi. ${ }^{19}$

Keseharian para Tuan Guru ini penuh dengan kesibukankesibukan yang cenderung menjauh dari masyarakat, entah mengurus partai, mengurus proyek, dan lain-lain. Dalam kasus ini, masyarakat sulit untuk mengadukan permasalahan-permasalahan sosial agama mereka sebagaimana yang lazim dilakukan di zaman dahulu. ${ }^{20}$

\section{c. Meninggalkan Kehidupan Sufistik}

Tuan Guru sebagai elit agama Islam pada masyarakat Sasak kuno menjadi penafsir agama tunggal, mengayomi, mengabdi kepada masyarakat, berdakwah ngamarin, memiliki murid tarikat, membuka pengajian, mendirikan pusat belajar ilmu agama (hanya untuk mendekatkan diri kepada Allah) adalah track record gelar Tuan Guru zaman dahulu (yang dapat terdengar dari cerita-cerita masyarakat, yang dapat dibaca dari buku-buku), kehidupan mereka

${ }_{19}$ Tuan guru dipandang lebih meme ntingkan urusan birokrasi dari pada berse ntuhan dengan umat.

20 "Mereka harus memilih antara jadwal pemerintah atau "Pesilaan" (undangan informal oleh masyarakat), kalau tuan guru tidak pernah meme nuhi pesilaan sudah jelas akan ditinggal jamaahnya." Abdul Aziz, Tokoh Adat Desa Peme nang, Kabupaten Lombok Utara. Wawancara , 20 Januari, 2015. 
kurang lebih berkutat pada hal-hal di atas. Karena pola kehidupan sufistik yang hanya para Tuan Guru yang mampu melakukannya, sedangkan masyarakat awam tidak mampu melakukan hal serupa, menjadikan mereka tokoh-tokoh yang dikeramatkan hingga puncaknya ziarah-ziarah para makam Tuan Guru yang menginspirasi, dianggap pada masa hidup mereka memiliki karomah, dan berkarismatik.

Berdasarkan rekam jejak (track record) di atas, seolah-olah pola sufistik yang menjadi gaya hidup para Tuan Guru zaman dahulu disematkan kepada semua orang yang bergelar Tuan Guru, masyarakat Sasak "memukul rata" individu-individu yang bergelar Tuan Guru dengan kehidupan sufistiknya. Akibatnya, ketika sebagian Tuan Guru tidak menerapkan gaya hidup sufistik di tengahtengah masyarakat, seolah terjadi kekecewaan terhadap Tuan Guru "under estimated". Idealitas dan realitas Tuan Guru kembali dipertanyakan, kekecewaan otomatis timbul dari sumber pemberi legitimasi yakni masyarakat.

\section{d. Gaya Hidup Glamor}

Selanjutnya penting kiranya untuk dikemukakan apa yang kami maksud gaya hidup glamor ala Tuan Guru. Tentu saja dalam empirisnya tidak akan ditemukan glamor dalam pengertian umum yakni "yang serba gemerlapan"21, Tuan Guru pergi ke club-club di Senggigi, Café di Gili Trawangan, Mall di Mataram, tempat karaoke di berbagai kota kabupaten di Lombok dan di tempat-tempat lainnya, namun maksud kami adalah sifat boros, menghambur-hamburkan uang dalam ritual berhaji atau umroh sedangkan masyarakat di sekitar tetap miskin dan melarat, atau kalau boleh kami sematkan dengan istilah "religious laundry"22 dan dalam bahasa Sasak disebut tradisi roah.

${ }^{21}$ Kbbi Ofline .

${ }^{22}$ Saat para Tuan Guru Nahdlatul Wathan melakukan purifikasi. Lihat, L M. Ariadi. Haji Sasak, hlm. 3 


\section{Penutup}

Demokrasi memberikan ruang bagi siapa saja untuk menjadi seorang penguasa formal, melalui mekanisme pemilihan umum dengan prolehan suara terbanyak. Tuan Guru dalam demokrasi berpotensi memenangkan kontestasi pemilihan karena memandang basis masa yang ada di pondok pesantren. Dengan modal basis masa santri, orang tua santri dan jamaah pengajian serta tim pemenangan di luar struktur pondok pesantren menjadi itung-itungan ril untuk mendaftarkan diri sebagai peserta pemilu. Namun basis masa dengan alasan karisma yang dimiliki tersebut belum mampu mengantarkan sebagian mereka memenangkan kontestasi pemilihan umum, ada beberapa faktor di antaranya: perubahan sistem pemerintahan, perselingkuhan Tuan Guru dengan penguasa, beda afiliasi dengan pengikut, pragmatisme para pemilih, poligami, gaya hidup elitis konsumtif, meninggalkan kehidupan sufistik, gaya hidup glamor.

\section{Daftar Pustaka}

Abdul Wahid, Populisme Akar Ketahanan Politik Identitas: Refleksi

Pasang Surut Politik Islam dari Orde Lama hingga Orde Reformasi, dalam Jurnal Penelitian dan Kajian Keagamaan (Dialog), (vol. 72. no. 2, Tahun. XXXIV, Nopember 2011).

Bianca J Smith, Stealing Women, Stealing Men: Co-creating Cultures of Polygamy in a Pesantren Community in Eastern Indonesia, (Report Information from ProQuest, 30 April 2015 11:21).

Data dari Komisi Pemilihan Umum (KPU) Provinsi Nusa Tenggara Barat. Tahun 2014.

Data, KPU Kabupaten Lombok Timur Tahun 2005.

Data, KPU Kabupaten Lombok Timur Tahun 2014.

Data, KPU tingkat Kecamatan, NTB, 2014.

Imam Subkhan, Karisma dan Hegemoni Politik Kiai dalam Kompas,

13 Maret 2004.

Komarudin dan Haryono, Maneuver Politik Ulama "Tafsir Kepemimpinan Islam dan Dialektika Ulama-Negara" (Yogyakarta: Jalasutra, 2004). 
L M. Ariadi, Haji Sasak “Sebuah Potret Dialektika Haji dan Kebudayaan Lokal”, (Ciputat: Impressa, 2013).

Masnun, Tuan Guru KH Muhammad Abdul Majid, Gagasan dan Gerakan Pembaharuan Islam di Nusa Tenggara Barat, (Jakarta:Pustaka al-Miqdad, 2007).

Miftahussurur, Pasang Surut dan Pragmentasi Politik Islam di Indonesia, dalam Jurnal Penelitian dan Kajian Keagamaan (Dialog), (vol. 72. no. 2, Tahun. XXXIV, Nopember 2011).

Nazar Naamy, Politik Tuan Guru "Idealitas Moral dan Pragmatisme" (Mataram: Sanabil: 2016)

Zuly Qodir, Islam Syariah vis-à-vis Negara “Ideology Gerakan Politik di Indonesia", (Yogyakarta: pustaka pelajar, 2007). 
